PARECERES

\title{
Parecer da Comissão de Classificação de Cargos
}

Processo $n^{2}$ 2.266-63 - Propostas de Readaptação de funcionátios de diversas categorias, pertencentes ao Departamento Administrativo do Serviço Público.

\section{PROCESSO $\mathrm{N}^{\circ} 2.266-63$}

Trata o presente processo de propostas de readaptação de funcionários do D.A.S.P., seguintes:

$\left.1^{\circ}\right)$ de Romilton Pimentel dos Santos, ocupante do cargo de mensageiro para Escrevente-Datilógrafo AF 204 Proc. 5.448-62.

2) de Wanderley Theodoro Viana, ocupante do cargo de Oficial de Adrinistração para Técnico de Administração AF 601.17A. - Proc. 2.386-61.

$3^{\circ}$ ) de Odilia Quirino da Silva, ocupante do ca:go de Oficial de Administação para Técnico de Administração AF 601.17A. - Proc. 2.655, de 1961.

$\left.4^{\circ}\right)$ de Neide Ramirez Deleito Barbosa, ocupante do cargo de Escriturário para Bibliotecário EC 101.12-A. Proc. $11.354-60$ anexo ao 2.265 de 1961.

$\left.5^{\circ}\right)$ de Sebastiăo Monteiro Ramos, ocupante do cargo de Mensageiro, para Inspetor de Alunos Ec 204.9. A. Proc. 30.457-63.

6.) de Maria Inês dos Santos, ocupante do ca-go de Escrevente-Datilógrafo, para Inspetor de Alunos EC 204.9-A. - Proc. 30.479-63.

$7^{\circ}$ ) de Israel Guimarães, ocupante do cargo de Auxiliar de Portaria, para Fotógrafo P 502.9-A. - Proc. 2.456 de 1961 .
8) de Marcelino Ferreira Bastos, ocupante do cargo de Técnico de Administração para Assesser Parlamentar. - Proc. 7.506-63.

$\left.9^{\circ}\right)$ de Waldyr da Fontoura Cordovil Pires, ocupante do cargo de Escriturário para Assistente Juridico. Proc. 2.382-61, anexados 7.506-63 e 11.656-63.

O exame das propostas obedeceu a nova a-ientação traçada pelo Decreto n* 52.400, de 25 de agôsto de 1963 .

O Grupo de Trabalho previsto no citado Decreto $\mathrm{n}^{2} 52.400$ opinou favoràvelmente às propostas de readaptação, por entender comprovado o desvio funcional. O representante da $\mathrm{Di}$ visão de Classificação de Cargos do D.A.S.P. concordou com o pronunciamento do Grupo de Trabalho, ressalvando apenas quanto às últimas duas propostas:

a) quanto a Marcelino Ferreira Bastos, processo 7.506-63, porque entende ser necessário a fixação das atribuições de Assessor Parlamentar, cargo criado fora do Sistema de Classificação, sem exame do mérito dos trabalhos apresentados e executados pelo readaptando; e

b) quanto a de Waldyr da Fontoura Cordovil Pires, processo 2.382-61, repetindo o entendimento da D.C.C. que atribui, como nos processos anterio'es de readaptação para o cargo de Assistente Juridico, as tarefas de conteúdo jurídico como atribuição do Técnico de Administração, em que poderia ocorrer a readatação do funcionário em causa.

A preliminar levantada pela D.C.C. de se condicionar a concessão de readatação à fixação de atribuições de cada classe não é coisa nova, tendo 
constituido grandes controvérsias nesta Comissão por ocasião da votação do processo de $\mathrm{n}^{2}$ 892-61, de interésse de José Silvestre Fernandes Filho. Na época o entendimento fixado foi o resultante do voto de desempate proferido pelo nosso ilustre colega $\mathrm{Dr}$. Waldyr dos Santos que presidia a Comissão, prevalecendo que as readaptações não dependiam de especificações de classes. Eis o voto:

- Desempato, adotando o ponto-devista do Dr. Luiz Rodrigues. Não desconheço as dificuldades da D.C'.C. Mas, por mais intransponivel que elas sejam entendo que a paralizaçăo dos processos de readaptação redunda $\mathrm{em}$ evidente postergação do direito dos readaptandos e importam numa inversão dos princípios estabalecidos na Lei $\mathrm{n}^{2} 3.780-60$. De fato, não há a menor justificativa para o procedimento adotado pela D.C.C. do D.A.S.P.: se inexistem especificações de classe aprovadas mediante regulamento, na forma do art. $6^{\circ}$ da mencionada Lei $n^{\circ} 3.780$ de 1960 , as conseqüências năo podem alcançar os servidores nas condições do requerente, eis que o mesmo diploma legal estatui no seu art. 83, que as regulamentações necessárias à execuşão . daquela lei, deveriam ser baixadas dentro de cento e vinte (120) dias de sua publicação. A protelação "ad infinitum" da regulamentação necessária, importa evidentemente, em alcance ao direito dos servidores em condições de readaptar-se, mormente sabendo-se que a readaptação, nos têrmos do artigo 46 , só produzirá efeitos "a contar da data da publicação do decreto no Diário Oficial": A postergação é indefensável não seria justificada pelas dificuldades da Administração na elabo:ação da tarefa que lhe incumbe.

Em face de todo o exposto, concluo o meu voto no sentido de que sejam instruidos e encaminhados à apreciação desta Comissão o.s processos c'e readaptação, iniciados "ex-officio" ou a pedido.

Assim, discordo da D.C.C. para adotar o entendimento anteriormente votado, por ser mais consentàneo oom o meu pensamento de fazer justiça, principalmente porque ao ser criad, o o cargo de Assessor Parlamentar, ficou de ce:ta maneira definida a atribuição do referido cargo, sendo que devo acrescentar aqui ser essencial que o readaptando tenha além de respondido o que o Congresso nerguntou, tenha também elaborado mensagens, redigido razões de veto e tenha dado parece:es sôbre os projetos de lei, esclarecendo as conveniências de adução ou não, ficando destarte afastado aquêle que apenas encaminhou expediente ao Congresso.

O Grupo de Trabalho entendeu que ficou provado o desvio da funçăo pelo exercicio de atribuições pertinentes ao cargo de Assessor Parlamentar e que ficou compiovado:

a) estudo de projetos $\mathrm{e}$ anteprojetos de leis em tramitação no Congresso;

b) elaboração de mensagens $\mathrm{e}$ anteprojetos de leis de iniciativa do Poder Executivo;

c) ter redigido razões de vetos na comprovação das atividades como acima consta do processo;

a) por atestado passado pelo então Chefe da Asessoria Parlamentar da Presidência da República, confi-mando as atribuições citadas no item anterior.

b) atestado firmado pelo então Che$\mathrm{fe}$ do requerente no D.A.S.P., Dr. Waldyr dos Santos, citando atribuições do serviço referido no item anterior;

c) minutas de parece:es e projetos e razões de vetos de sua autoria com datas que abrangem o período (fôlhas 6 e 36) do desvio funcional;

d) ofícios do Chefe da Assessoria Parlamentar da Presidência da República distribuindo projetos de lei em tramitação no Congresso Nacional para parecer do readaptando.

$\mathrm{O}$ a, por mais profundo que sejam os estudos para a fixação das atribuições de Assessor Parlamentar, as tarefas do readaptando serão sempre as principais de um Assessor Parlamentar, não seria justo protelar-se para se chega- a uma mesma conclusão.

Tenho para mim como improcedente a restrição apresentada pelo represen. tante da D.C.C.

Discordo, também da D.C.C. no tocante a restrição à readaptação de Waldyr da Fontoura Cordovil Pires para Assistente Jurídico, ficando com o 
pensamento desta Comissão que já se manifestou muitas vêzes sôbre o assunto e no processo $n^{2} 100-63$, de interêsse de Vicente Ferrer Corrêa Lima a Comissão decidiu:

"As atividades juridicas são privativas dos cargos de natureza Juridica, como óbvio, assim a sua atribuição a cargos que não sejam juridicos, sob pena de se tornarem insubsistentes as regulamentações das profissões.

Outra não foi a orientação seguida por esta Comissão, aprovando o voto do nosso companheiro ilustre Dr. Fernando Figueiredo Abranches, nos casos de readaptação de funcionários do D.A.S.P.: - Alberto da Cruz Bonfim (Proc. 622-63), Corsindio Monteiro da Silva (Proc. 522-63), Hugo Luiz Gurjão de Melo (Proc. 531-63). Cicero Fernandes (Proc. 1.382-63), e de Benedito Pedro da Silva (Processo $\mathrm{n}^{\circ}$ 1.243-63). Não veja porque alterar essa orientação que nos parece ace:tada.

Opino, assim, pela aprovação das readaptações propostas, com parecer favorável do Grupo de Trabalho ins- tituido pelo Decreto $\mathrm{n}^{\circ} 52.400$, de 25 de agôsto de 1963, certo de que estou fazendo justiça.

Comissão de Classificação de Cargos, em 11 de outubro de 1963. Ranor Thales Barbosa da Silva, Relato:.

\section{DECISÃo}

Como consta da ata, o Plenário da Comissão aprovou, po: unanimidade, o voto do Relator, salvo no caso de Waldyr da Fontoura Cordovil Pires em que o membro Senhor Raymundo Xavier de Menezes votou contra, abstendo-se de votar em relação a Marcelino Ferreira Bastos, tendo em vista as razões do representante da D.C.C.

Sala das Sessões, em 11 de outubro de 1963. - Ranor Thales Barbosa da Silva, Presidente. - Waldyr dos Santos, Vice-Presidente. - Raymundo Xavier de Menezes, Membro. - Fernando Figueiredo de Abranches, Mrembro.

Publicado no D.O. de 17-1-964, Suplemento ao $\mathrm{n}^{\circ} 12$, Seção I, Parte I, pág. 49. 